Article

\title{
Is Europe Cascading into Fascism? Addressing Key Concepts including Gender and Violence
}

\author{
Sylvia Walby \\ Department of Sociology, Lancaster University, Lancaster, LA1 4YW, UK; E-Mail: s.walby@lancaster.ac.uk
}

Submitted: 25 February 2018 | Accepted: 4 July 2018 | Published: 14 September 2018

\begin{abstract}
Is Europe cascading into fascism? The answer to this question matters for understanding the opposition to gender equality projects in Europe. The article addresses some of the key concepts needed to answer this question. Is 'fascism' or 'authoritarian neoliberalism' or just 'neoliberalism' the most appropriate concept to capture the turn to the right? The article compares the extent to which these concepts encompass 'violence' and 'gender'. 'Fascism' is an important benchmark from European history, but Europe has not yet reached its levels of violence. The qualifier 'authoritarian' is not needed for 'neoliberalism' since it generates a trajectory towards violence. Some conceptual work is required in order to develop 'neoliberalism' to encompass 'gender' and 'violence', but there are bodies of work that support such a development. Including gender in analyses of the macro level changes occurring in Europe requires the concept of 'varieties of gender regime', which enables the conceptualisation of neoliberalism as gendered.
\end{abstract}

\section{Keywords}

Europe; fascism; gender; violence

\section{Issue}

This article is part of the issue "The Feminist Project under Threat in Europe", edited by Mieke Verloo (Radboud University, The Netherlands) and David Paternotte (Université Libre de Bruxelles, Belgium).

(C) 2018 by the author; licensee Cogitatio (Lisbon, Portugal). This article is licensed under a Creative Commons Attribution 4.0 International License (CC BY).

\section{Introduction}

Is Europe cascading into fascism? This question is becoming central to understanding the opposition to gender equality projects in Europe. This article addresses some of the key concepts needed to answer this question. Is the turn away from social democracy best thought of as fascism, or as an intensification of neoliberalism or as authoritarianism? How should variations in gender relations be conceptualised at a macro level, in addition to the meso and micro, so that they can be included in this discussion? How can violence, which is so important in the constitution of gender relations and the opposition to feminism and gender equality, be included in the conceptualisation of major social changes?

These questions are posed in the context of a turn to the right in Europe that opposes the gender equality project. This rightward turn could be benchmarked against the rise of fascism in Europe a century ago after a financial crash, recession, cuts in government expenditure, and exacerbation of national/ethnic/religious divisions. Fascism is a multi-faceted far right project that includes opposition to gender equality and the use of violence to pursue its ends. However, are concepts other than fascism, such as neoliberalism or authoritarianism, more appropriate for today?

Debates on changes in neoliberalism (Bruff, 2014; Streeck, 2014) and the possibility of fascism (Robinson \& Barrera, 2012) raise questions about the place of violence in trajectories of decline and the significance of gender and other inequalities beyond class. 'Violence' is a distinct form of power that is gendered. Addressing 'Europe' concerns not only political economy, but also the institutions that shape violence. Whether current developments entail the rise of fascism requires a clarification of whether the concept of neoliberalism sufficiently addresses violence as well as political economy. There are some indications that violence against women and mi- 
noritized groups is increasing. But the concept and analysis of violence is often marginalised in theories of macro social change (Malešević, 2010; Walby, 2013). The article addresses the implications for macro level analysis of including violence in social theory so that gender can be fully addressed in current developments.

The significance of gender relations for these issues is now well established at micro and meso levels, with scholarship documenting and analysing changes in the gender equality project and gendered institutions (Abels \& Mushaben, 2012; Ahrens, 2018; Chappell \& Waylen, 2013; Jacquot, 2015; Verloo, 2018; Waylen, 2007). At the macro level, there has been some development of the analysis of gender (Connell, 1987; Lewis, 1992; Lombardo, 2017; Walby, 2009). However, there remains considerable segregation of the mainstream and gender fields at the macro level of analysis. The purpose of the article is to contribute to developing a synthesis that will more adequately enable gender issues to be included in the debates about current societal transformation at a macro level of analysis.

\section{Social Democratic, Neoliberal, Authoritarian or Fascist?}

\subsection{Introduction}

The starting assumption is that it is possible to distinguish between different forms of society at a macro level and that these are gendered. Assessing which conceptual distinctions are most important requires consideration as to where the boundary between them should be drawn. The criteria for making this assessment include not only those used by the 'mainstream' but also the ability to capture distinctions relevant for 'gender', which requires addressing 'violence'.

There are at least three alternatives to conceptualising, at a macro level, the current turn to the right in Europe away from social democracy: neoliberalism; authoritarianism; and fascism. For the understanding of current changes, it is important to deploy concepts that can address violence as well as the polity, economy and civil society. Each of the macro concepts invokes a different positioning of violence in relation to other forms of power. Similarly, it is important to deploy concepts that can address gender and intersecting inequalities.

\subsection{Neoliberalism}

The concept of 'neoliberalism' has been deployed to signify right-moving projects and social formations (Harvey, 2005). But its relevance to the contemporary situation is weakened by its focus on political economy to the relative neglect of violence and by its focus on class to the relative neglect of gender and other intersecting inequalities. Can the concept be stretched so that it more adequately includes violence and gender, or should a different concept be used?
Neoliberalism is a political project, which has in some places become a governmental programme and in some a type of social formation. The social scientific approach to the analysis of neoliberalism as a project, governmental programme and social formation has typically been focused on political economy; but there are attempts to widen the concept. This raises issues concerned with the internal coherence of the concept, and its relationship with violence and with gender and intersecting inequalities.

The early articulation of neoliberalism in its own terms can be found in the work of Hayek (1944/2001) and Friedman (1962/2002). Neoliberalism draws on traditional liberalism in its central tenet that the purification of markets from interference is the best route to economic efficiency and political freedom; but goes beyond this in explicitly seeking the support of the state to achieve pure markets. It is important to take this seriously in its own terms as well as to analyse its contradictions (Gane, 2014). There is a fundamental tension between the rhetoric of seeking to remove state regulation of economic markets and the practice of utilising the power of the state to make markets. Despite the role of neoliberal beliefs about markets in the causation of the financial and economic crisis, these remains hegemonic within mainstream economics (Crouch, 2011), although heterodox approaches have long existed (Minsky, 1986/2008). There are variations in the development of neoliberalism in practice (Brenner, Peck, \& Theodore, 2010; Ong, 2006; Peck, 2010), but market fundamentalism remains its core.

Applying the concept of neoliberalism to the European Union (EU), Streeck (2014) sees only a process of de-democratisation, increasing inequality, and the EU as having become a neoliberal machine. But, this depends on his use of a lens narrowed to class. This account of the EU is challenged when gender is brought into focus. Can the reach of the macro level concept of neoliberalism be widened to include gender and other inequalities to assist analysis of changes in the EU?

Most of the scholarship on gender and Europe has focused on the meso level of changes in specific gendered institutions (Cavaghan, 2017; Chappell \& Waylen, 2013), although there are significant exceptions. Among the gendered macro-oriented analysis there are three approaches. The first treats neoliberalism as if it were contemporary capitalism and does not make significant distinctions between varieties of capitalism. It treats EU economic policy as if it is in evitable tension with EU social policy. This approach rejects, often implicitly rather than explicitly, the notion that there is more than one variety of capitalism. Since the premise here is that there are differences in the forms of capitalism, this approach is not further discussed. The second approach focuses on the gendered division of labour between domestic care work (or reproduction) and waged work (or production) and identifies variations in how this is organised at a macro level (and is discussed below). The third identifies distinc- 
tive forms of gender regimes and includes not only political economy but also violence at a macro level (and is discussed and developed in the rest of the article).

The second approach to the macro level conceptualisation of gender in Europe has often focused on varieties of households, on whether there is a sole breadwinner or dual earners (Lewis, 1992) and the role of the welfare state in this (Jenson, 1997), or on the balance between production and reproduction in women's work (Elson, 2002). This challenged the mainstream account of welfare state regimes as led by class relations (Esping-Andersen, 1990), but has not become fully integrated (Emmenegger, Häusermann, Palier, \& SeelibKaiser, 2012), despite empirical scholarship showing the complex inter-relationship of gender and class relations (Schäfer \& Gottschall, 2015), and the significance of new forms of organisation of care involving markets as well as states (Gottfried, 2015). Attempts to gender European integration theory face similar challenges: on the one hand the empirical evidence of the significance of gender might be considered overwhelming (Abels \& MacRae, 2016); on the other, in so far as the challenge pulls back from addressing the conceptualisation of the macro level (Bieling \& Diez, 2016), it is not transformative of the mainstream. Hence, the analysis here draws largely on the scholarship that contributes to the re-gendering of the macro level (Lombardo, 2017; Mahon, 2010; Walby, 2009; Wöhl, 2014).

\subsection{Authoritarianism}

The significance of violence is a challenge to those who confine the concept of 'neoliberal' to political economy. Bruff (2014) responds to this challenge by arguing for the qualification of the term 'neoliberal' by 'authoritarian': 'neoliberal authoritarianism'. Wacquant $(2009,2010)$ addresses it by extending the concept of neoliberalism to include state coercion. However, neither Bruff nor Wacquant significantly address issues of gender.

There are well-developed literatures on violence against women (Krizsan \& Popa, 2010; Weldon \& Htun, 2012; Zippel, 2006), and on gender and security (Guerrina, Chappell, \& Wright, 2018; Kronsell, 2016), but neither have yet been integrated into mainstream accounts of macro level variations in society.

One response to the traditionally narrow definition of the concept 'neoliberalism' is to use the term 'authoritarian' in order to signal the significance of a coercive state, of violence and of the move to securitisation. Bruff (2014) develops a concept of 'authoritarian neoliberalism', thereby qualifying neoliberalism with the term 'authoritarian'. He argues that it is 'qualitatively distinct', citing the 'increasingly punitive nature of penal and criminal policy: under authoritarian neoliberalism dominant social groups are less interested in neutralizing resistance and dissent via concessions and forms of compromise that maintain their hegemony, favouring instead the explicit exclusion and marginalization of subordinate so- cial groups through the constitutionally and legally engineered self-disempowerment of nominally democratic institutions, governments, and parliaments' (Bruff, 2014, p. 116). Bruff thus argues for the importance of coercion; and that this should be recognised by this concept.

The advantage of the concept 'authoritarian' is that it addresses the decrease in democratic depth that is occurring in the real world and the significance of the relationship between state and civil society in this change thereby opening the door to a consideration of the significance of coercion. However, the disadvantage of this formulation is that it de-links the development of coercion and de-democratisation from the project of neoliberalism, as if it were possible to have neoliberalism without these developments (Wacquant, 2009, 2010).

Wacquant $(2009,2010)$ extends the concept of neoliberalism to address the development a punitive criminal justice state. Rather than seeing the developing punitive nature of penal practices as either a 'culture of control' (Garland, 2001) or in tension with the rest of the state (Bourdieu, 1994), Wacquant interprets the turn of the state from penal welfare to a punitive approach as a core part of the neoliberal project. It is necessary to contain, control and punish the poor that are generated by the neoliberal project in government: 'a proactive penal system is...a constituent component of the neoliberal Leviathan' (p. 200). Wacquant understands his analysis as breaking away from a 'thin economic conception of neoliberalism' (p. 200); and that 'neoliberalism entails the enlargement and exaltation of the penal sector' (p. 211). Implicit in Wacquant's account is the notion that those who are imprisoned are the victims of the capitalist system. However, some of these imprisoned people are perpetrators of violence, including violence against women (Walby, Towers, \& Francis, 2016) and against minoritized groups (Ray \& Smith, 2001). The complexity of these multiple inequalities of gender as well as of class eludes Wacquant. This is despite a well-developed field on gender and violence (discussed below in the section on violence).

As Walby (2009, 2015) shows, there is a link between neoliberalism and violence because the increased inequalities generated by neoliberalism generate increased violence. Indeed, as Walby argues, neoliberalism, while purporting to shrink the state in relation to the economy, grows it in relation to violence, producing a larger and more coercive state, not a smaller state thereby producing the things it rhetorically claims to oppose. The conclusion is thus that since neoliberalism generates a coercive state, despite its rhetoric of promoting a small state; it is not necessary to qualify the term neoliberalism with authoritarian to capture this.

\subsection{Fascism}

'Fascism' is a further potential concept. Most analyses of fascism have been centred on Nazi Germany, extending to adjacent European countries in the middle of the 
twentieth century (Mann, 2004). The potential application to the current period has been largely tentative (Robinson \& Barrera, 2012).

Mann (2004, p. 13) defines fascism as 'the pursuit of a transcendent and cleansing nation-statism through paramilitarism', thereby invoking five concepts: nationalism, statism, transcendence, cleansing and paramilitarism. Threaded through is the concept of violence, which is an instrument of the project of creating the purity of the nation-state. It includes violence from below, as well as by an authoritarian state. Mann's account of fascism is centred empirically on mid-twentieth century Europe.

Robinson and Barrera (2012, p. 8) identify the 'protofascist' response to the current crisis as involving 'militarism, extreme masculinisation, racism, the search for scapegoats (such as immigrant workers and Muslims in the USA and Europe) and mystifying ideologies'. They do not think that there is yet fascism in the USA or Europe, but that there are 'fertile bases for projects of twentyfirst century fascism' (2012, p. 10). 'States resort to a host of mechanisms of coercive exclusion: mass incarceration and prison-industrial complexes, pervasive policing, repressive anti-immigrant legislation, manipulation of space in new ways so that both gated communities and ghettos are controlled by armies of private security guards and technologically advanced surveillance systems, and ideological campaigns aimed at seduction and passivity through petty consumption and fantasy'. These processes are linked to a 'global capitalism' associated with an expanded 'global superfluous population' (p. 16). 'Criminalisation of the structurally marginalised and the militarisation of their control are major mechanisms of pre-emptive containment'.

The advantage of the concept is that it explicitly addresses the use of violence by the state and groups in civil society to pursue the goals of 'purity' that apply to all forms of social relations and inequalities, including nation, ethnicity, religion, gender, sexuality and disability. It implies a total societal formation, not only a focus on the state, though that is often its main site of analysis. The disadvantage is that, for some, it is a term that is specific to time and place of Germany and Italy in the 1930s and its extension can be considered not only historically inaccurate but also 'culturally' offensive.

In Europe, the concept of fascism has resonance and utility. There may be no actually-existing European example today, but fascism in European history provides a point of reference and comparison for contemporary theorising.

\subsection{Social Democracy}

The fourth variety of society considered here is that of social democracy. It may be that it is more historic than currently developing, but it is important both to benchmark the past and to maintain an imaginary, or vision, of an alternative future. Social democracy can be concep- tualised as a project, programme and social formation that is the 'other' to neoliberalism. Traditionally, the lead concepts have focused on political economy and class (Streeck, 2014), with violence and gender often left out of focus. However, there has long been a literature that has sought to demonstrate the significance of gender and feminism for the construction of social democracy (Durbin, Page, \& Walby, 2017; Huber \& Stephens, 2000; Mahon, 2010). The significance of feminism is often underestimated, partly because it is insufficiently visible in the public domain, and partly because of an overly restrictive definition of feminism that limits it to identitybased practices and omits broader coalitions between feminist and other progressive forces (Walby, 2011). Social democracy is an important 'other' to neoliberalism and fascism, and remains an important benchmark, even if few if any actually existing societal formations come close to its realisation today.

\section{Violence}

Violence has been increasing in Europe in recent years: the increased practice and salience of violence are part of the changes in Europe under assessment. Within the varieties of societal forms discussed in the previous section, violence might be considered core to fascism, routine in authoritarianism, collateral damage for neoliberalism, and less common in social democracy. Variations in society are constituted by variations in violence as well as in political economy. The assessment of the form of society is significantly dependent upon the extent and significance of violence. Violence is a constituent part of the gender regime; so, changes in gendered violence are changes in gender inequality. The increase in violence is one part of the threat to the feminist project of gender equality. Violence concerns not only crime, but also war, peace and security. The response of the state to violence and to perceptions of violence is part of the institution of violence. Integrating the insights from gender analysis about violence into the theorisation of macro changes in society is challenging. It requires addressing: the conceptualisation of violence, the link between violence and gender; and the link between variations in violence and other institutional domains.

\subsection{The Concepts of Violence and Security}

Violence is a core component of the concepts of crime, peace, war and security. There are several different forms of violence: inter-personal, e.g., violent crime; group, e.g., terrorism, genocide; state, e.g., capital punishment; harsh policing; inter-state, e.g., war. The concepts of violence and security overlap: in some disciplines, violence is the term most often used, for example, criminology and sociology; in others it is security, for example, political science and international relations.

Definitions of violence in use in the social sciences range from broad (Bourdieu, 1994; Galtung, 1996) to nar- 
row (Collins, 2008). Broad approaches that effectively equate violence with other forms of power or harm make it hard if not impossible to analyse what causes violence, since the various concepts for power are merged into one (Walby, Towers, \& Francis, 2014). By contrast, a narrower, more specific approach, enables analysis of the relationship between violence and other forms of power. The specificity of violence as a form of harm is that it involves the physical and involves intention (Walby et al., 2017). Violence is here conceptualised as an institution (Walby, 2009). Institutions embed practices associated with violence. An institution is a self-reproducing system; it reproduces regardless of the agency, intention or the individuals who make up the institution. Violence is an institutional domain in which diverse types of violence are inter-connected, approximately equivalent to institutional domains of economy, polity and civil society. For example, if the rate of one form of violence is high, then the rate of other forms of violence is also likely to be high. The institution of violence includes actions and reactions; practices and responses; deployment and regulation. States usually respond to violence in civil society and by other states. States may use violence to attempt to end violence, or they may deploy other repertoires of action.

The concept of 'security' can contain explicit or implicit reference to violence. Traditionally, the concept of security referred to inter-state relations and was focused on war. There are variations in the extent to which violence is used in externally facing security strategies; and the EU has developed a Security Strategy that is less dependent on violence than that of the USA (Smith, 2003). The concept of security has sometimes been extended to include non-state relations (Kaldor, 2007), internal relations concerning unnecessary harm and those on the boundary of internal and external relations (Bigo, 2006). Security strategies often contain theories of violence, defined narrowly or broadly: 'hard' security strategies more invoke violence than 'soft' security strategies. The ability to define a situation as in need of a security response is an important form of political power (Buzan, Wæver, \& de Wilde, 1998).

\subsection{Gender, Violence and Security}

Violence and security are gendered. Within interpersonal violence, this has been addressed as genderbased violence and violence against women (Kelly, 1988; Walby et al., 2015; Walby et al., 2017); sometimes including analysis of the varied role of the polity (Lewis, Dobash, Dobash, \& Cavanagh, 2001), including its European dimension (Krizsan \& Popa, 2010; Zippel, 2006). A significant body of literature on the significance of gender for security has developed, with special attention to the transnational level (Guerrina et al., 2018; Kronsell, 2016).

Violence is a constituent part of the gender regime: cause and consequence of gender inequality (Walby, 2009).

\subsection{Variations in Violence and Coercion}

Violence is endemic in society; but there are important variations in the rate of violence and in state responses to it. There is evidence of current increases in violence (Walby et al., 2016). Variations in rates of violence have been linked to: economic and political inequality (Merton, 1938); the modernisation of the state (Weber, 1922/1968); and crisis and social change (Gramsci, 1971).

Although there has been a long-run decline in violent crime, there is evidence of a current increase. There had been a long-run decrease in violence over centuries in Europe (though with some fluctuations), according to empirical data on homicide rates (Eisner, 2001; Pinker, 2011). However, there is also a recent increase in interpersonal violence and in terrorism. Violent crime has been increasing since the economic crisis of 2008, at least in England and Wales, driven by an increase in violence against women and domestic violence according to evidence from the Crime Survey for England and Wales (Walby et al., 2016). There was a spike in hate crime immediately following the Brexit Referendum in the UK on 23 June, 2016, with a significant increase in on-line reports to police (National Police Chiefs' Council, 2016).

Variations in state violence and coercion towards individuals are complex. Traditionally, it has been argued that the stronger the state and the rule of law, the less likely is violence between citizens; a process that has been increasing with 'modernity' as the state acquires a monopoly of legitimate violence in its territory (Tilly, 1990; Weber, 1922/1968). The link between modernity and violence is reinterpreted by Elias (1939/1994) as the development of individual self-control in individuals that is consequent on structural changes in the state. This link between modernity and self-control, which generates lower levels of violence, is apparently offered empirical support by Eisner (2001) and Pinker (2011) and is central to the theory of crime of Gottfredson and Hirschi (1990). The reduction in overt punishment by the state and its replacement with discipline is further developed by Foucault (1991). Foucault provides an account of a move away from a visibly coercive state (public executions) towards processes of disciplining in a range of institutions (from prisons to clinics) and most recently the self-securitisation of citizens.

The rate of violence is linked to levels of inequality. The association between violence and economic inequality is robustly established in empirical studies (Chiricos, 1987; Fajnzylber, Lederman, \& Loayza, 2002; Hsieh \& Pugh, 1993; Pratt \& Cullen, 2005). Violence is associated with a range of inequalities, including gender (Walby et al., 2016) and ethnicity (Ray \& Smith, 2001). The rate of violence is linked not only to economic inequality, but also to political inequality. The rate of femicide (killing of women) is lower in countries where there is a higher proportion of women in parliament (Walby, 2009, p. 299). 
Violence is an institution: practices of violence are interconnected and form a single institutional domain. There is a correlation between the level of different forms of violence: the more of one form, the more of other forms (Walby, 2009). Violence is an institutional domain that is shaped by the other institutional domains of economy, polity and civil society.

While the relationship between violence and inequality is robustly established, the directionality of this violence is challenging to many traditional theorisations of violence. The traditional assumption in criminology has been that violent crime is largely perpetrated by the disadvantaged against the advantaged (Merton, 1938). This has been challenged by evidence of the extent of violence against women (Kelly, 1988; Walby et al., 2014) and of hate crime against groups minoritized through ethnicity, religion, sexuality, disability and other characteristics (Ray, 2011). Variations in use of violence by the state (including the police) are associated with the depth of democracy: the more democratic the less coercive (Mansley, 2014; della Porta, 1995). Making violence visible changes the perceived direction of the violence between the powerful and the weak, defined in relation to multiple regimes of inequality.

\subsection{Implications for Theorising Europe}

How is the increase in violence to be theorised in analyses of the turn to the right in Europe? Paying attention to the nature of the inequalities and to processes of democratisation and de-democratisation is important.

The long fall in violence in Europe is reversing, driven, at least in Britain, by violence against women since the economic crisis of 2008 and against ethnic minorities during the political crisis of 2016; further there is widespread perception of an increased threat of terrorism. This rise in violence and in the perception of violence is part of the turn to the right. The modality of the state response to violence is complex and contradictory: it has been changing towards a more punitive criminal justice system in response to violent crime and increased securitisation in response to terrorism; but it has also involved response to gendered democratic pressures to intervene against rather than ignore violence against women. Changes in violence and the state have a gender dimension (the increase in violent crime is driven by violent crime against women) and a national/ethnic/religious dimension (the scapegoating of immigrants and asylum seekers).

The explanation of this change requires a theoretical framework in which violence has a significant place and one that can address its strongly gendered and eth$\mathrm{nic} /$ religious/national dimensions. A theoretical framework in which there is a continuum between social democracy and neoliberalism could stretch to encompass violence and societal variation. The separate identification of a form of society centred on 'authoritarianism' is not necessary, since the trajectory of neoliberal- ism includes the generation of coercive state capacity. The separate identification of 'fascism' is useful as a historical benchmark against which current developments can be compared.

\section{Europe, Gender Regimes, and Society}

Analysing changes in Europe concerning gender inequality requires theorising Europe as a society, not only a polity, or economy, or civil society, but also including violence. This also requires theorising gender at a macro level, as well as micro and meso levels.

Theorising changes in gender in Europe requires a theory of Europe as a society as well as a set of political institutions. Most current analyses of Europe focus on political institutions; although there are accounts of Europe that consider a broader range of social institutions. While Europe is often today theorised through the lens of politics or political economy, it was once understood as a wider set of institutions which included violence and civil society. Earlier discussions on the EU and violence focused on the emergent EU as a peace project (Haas, 1958; Hallstein, 1973); while today the EU has an Area of Freedom, Security and Justice. The EU is restructuring in response to the crisis. This has major implications for gender and other inequalities, although these are rarely explicit in the official texts.

The relative neglect of inequalities other than class in analyses of Europe is beginning to be addressed, although there is a tendency for the literatures on gender and class to be segregated (Kantola \& Lombardo, 2017). It is important to address the nature and significance of the intersection of multiple inequalities (Verloo, 2006; Walby, 2009).

\subsection{Beyond Europe as Polity}

Much analysis of the EU focuses on its political institutions. This includes the debate on the tension between member states and the EU-level in the discussions on EU integration (Milward, 1992; Moravcsik, 1993), which has a significant gender dimension (Abels \& MacRae, 2016; Lombardo \& Forest, 2011). Additional institutions and dimensions to 'Europe' and to 'integration' need to be considered in addition to these political institutions (Boje, van Steenbergen, \& Walby, 1999; Zielonka, 2006).

\subsection{Beyond Europe as Political Economy}

The development of political institutions takes place in a wider environment, including political economy. The political economy of scale and globalisation at the intersection of geography and other social sciences (Brenner et al., 2010; Harvey, 2005) offers much to the analysis of Europe even if that is not always its substantive focus. The contribution of political economy is to reposition debates about states as affected by the wider restructuring of the political economy. European member states and 
the EU are challenged to address global processes, not only national or regional ones. The greater mobility of global capital than labour shapes the balance of power and negotiated outcomes at the political level.

These debates tend to underestimate the significance of violence/security and of gender and other inequalities beyond class. This is despite a major debate on the changes in gendered divisions of labour (Lewis, 1992) and childcare (Mahon, 2010), which involves the structuring of the fiscal, which is of significance for the gendered welfare state.

\subsection{Europe and Violence}

With authority derived from the 2006 Treaty of Lisbon, the EU has been developing plans for ever deeper union that concern not only the Single European Market but also the European Area of Freedom, Security and Justice, which addresses violence and security. The European Commission (2017) White Paper on the Future of Europe: Reflections and Scenarios for the EU27 by 2025 offers options for potentially deepening cooperation in decisionmaking. This includes decision-making on security, on Schengen, migration, foreign policy and defence. While the European Commission (2017) pays little direct attention to equalities issues in these documents, they are of enormous significance for them because the subsidiarity boundary is gendered. The subsidiarity boundary is gendered, because the gendering of decision-making at the EU-level is different from the gendering of decisionmaking at member state level. So, changes in the location of the subsidiarity boundary will be affected by variations in the gender composition and priorities in these different locations.

The Treaty of Lisbon expanded EU competence to enhance an Area of 'freedom, security and justice'. These goals were to be met through a mix of 'mutual recognition' aided by limited harmonisation of laws and practices; and the creation of decision-making capacity at EUlevel. These competences have been mobilised to harmonise and develop legislation (Directives) on issues concerning gender-based violence, especially where there is an identifiable cross-border element.

Whether the enhancement of these EU-level powers over violence will be matched by an increase in the depth of gendered democracy or not is in question. The current insurgency from the right make this restructuring of the EU a precarious moment from an equalities perspective. Progressive gender forces potentially make a difference to the outcome; but these are challenging times for the feminist project. The theorisation of the EU requires the inclusion of violence situated in the context of changes in polity, economy and civil society.

\subsection{Europe as Society}

The theorisation of Europe as society (rather than polity or political economy) has a long history. One of the most important is Haas (1958), which focuses on the potential 'spillover' from one institution to another, that might lead to a form of European integration that is less prone to war and other forms of violence. From this perspective, the EU was invented so that never again would Europe experience war and holocaust. It was a project of intellectuals and politicians, of an epistemic community, jointly constructing a theory and a practice to realise this vision. The purpose of the EU was not to make money, but to make peace. The route to peace was circuitous. Although the target was clear-the nationalisms that had become militarised nationalisms in pursuit of states and purity, which were theorised as leading to war and holocaust-there was complexity in how the erosion of the nation-state projects was to be achieved. It was felt that there would be insufficient political support for such a project-the erosion of the nation-state-if it were to be directly proposed to the people of Europe in a democratic decision-making process. Instead, the project was to create the circumstances over the longer-term that would lead to regular crises that could only be resolved by ever closer union and which would generate the consent in civil society for this trajectory. Economic growth was not the end in itself. Economic unity was for a higher purpose, to generate the political conditions for the erosion of the nation-state project that had led to war and holocaust (Haas, 1958; Hallstein, 1969/1973). This approach entails a theory of society. It was not just a theory of political institutions. Not just a theory of political economy. Nor a free-standing theory of violence. Rather, a theory of society as a social system in which institutions of economy, politics, civil society and violence had mutual implications for each other. Within this approach to Europe as a potential society are ongoing debates as to the significance of different institutions for the whole, including that of the strengthening of democratic institutions (Habermas, 2012). While many of the mainstream texts on Europe as a multi-institutional society engage but little with the gender dimension, there are exceptions (Boje et al., 1999).

\subsection{Mainstreaming Gender into Macro Level Analysis of Europe}

Understanding changes in gender relations in Europe requires the utilisation of gender as a macro level concept as well as one at the meso level. Much macro level analysis of changes in Europe has used concepts and frameworks in which gender has been marginalised. The earlier discussion of concepts of neoliberalism, authoritarian neoliberalism, fascism and society democracy repeatedly noted the absence or marginal presence of gender relations. There has been much significant analysis of changes in gender relations at the meso level of specific institutions (Chappell \& Waylen, 2013; Lowndes \& Roberts, 2013; Waylen, 2007). But it is also necessary for gender to be addressed at the macro level of abstraction. 
It is necessary to mainstream gender into the macro level concepts to improve the theorisation of large scale changes in Europe. This means mainstreaming gender into the debates on the varieties of society as social democratic, neoliberal, authoritarian or fascist. This means engaging with these concepts rather than inventing new concepts for variations only in gender relations. Developing macro level concepts that are specific to gender relations (for example, types of breadwinner regimes) is not a viable strategy for mainstreaming gender into macro level social theory. It is necessary to have concepts that grasp both the specificity of variations in gender relations and variations in other sets of social relations including class simultaneously.

The concept of gender regime, and the distinction between its varieties at a macro level developed by Walby (2009) offers a way forward.

The development of the EU does not only concern specific political institutions, but is part of the restructuring of the relationship between political institutions, economy, civil society and violence. This development restructures regimes of inequality, even if equalities issues are not foregrounded in the public debates. The restructuring of political institutions in times of crisis is not only 'normal' for the EU, but also written into the design of its architecture. This requires a theory of Europe as a society, not only as a polity or political economy.

To address this multiplicity of social relations it is necessary to revise the concept of social system using complexity theory, as in Walby (2009). In this approach, each system takes all others as its environment. This practice, derived from Bertalanffy (1968), simplifies the analysis of the intersection of multiple inequalities. This enables the rejection of the assumption that the systems are nested or in a hierarchical relationship to each other - that is a matter for investigation. Sometimes systems can be very closely entwined-coupled. As systems interact, they mutually adapt-both change, rather than a one-way causal effect. Systems do not necessarily return to equilibrium (negative feedback loops) after they have been destabilised (perturbed)-though they may. Sometimes systems may move further away from equilibrium (positive feedback loops). A small cause may have a large effect, especially if a system or interacting systems are unstable-changes can be non-linear and not proportionate. These are the insights and practices of complexity science, which make the analysis of multiple intersecting inequalities more effective (Walby, 2007, 2009).

Addressing the issues of violence and multiple inequalities requires a theory of society, not only of political institutions or political economy. A theory of society requires a theory of social systems, which is best developed drawing on the insights of complexity theory. If the concept of neoliberalism is to stretch to assist, it needs to encompass a theory of a neoliberal social formation (and a contrasting concept, such as social democracy, as its other); and the dynamics of class and gender must not be conflated.

\section{Conclusion}

It is important to retain the concept of fascism as a benchmark, at least in Europe. Europe is not fascist now. Whether it becomes so again is an open question.

The concept of neoliberalism is retained for the conceptualisation of contemporary Europe, with social democracy as its main 'other'. The concept of authoritarianism potentially had the advantage of drawing attention to coercion and violence, which are often left out of focus in discussions of neoliberalism that are centred on political economy. While it is useful to draw attention to the 'authoritarian' features of contemporary neoliberalism in Europe; this does not require revision of the term 'neoliberal'. Indeed, it is better not to treat authoritarianism as 'other' to neoliberal, since authoritarian practices by the state are a common outcome of the trajectory of neoliberalism. At the heart of neoliberalism is a contradictory stance towards the state: in rhetoric, it is reviled and the subject of claims that it will be reduced so that the market can be freer and thereby function more efficiently; while, in practice, it is recognised as the necessary instrument to develop markets. While state engagement in social welfare and security is reduced by outsourcing to the private sector, state coercive activities are expanded in response to the violence generated by increasing inequality. As the state reduces the scope of its traditional monopoly over legitimate violence by permitting the extraction of profit from 'security', it increases the likelihood of violence and the desire to address it through more security (Walby, 2015). This is a contradiction at the heart of neoliberalism. The concept of neoliberalism should be retained, since it makes this contradiction more visible than if an alternative concept, such as authoritarianism, is deployed. However, this does require theorists to develop a full theory of society, which includes violence; not one that is narrowly focused on political economy.

Most of the analysis of neoliberalism that engages with the social relations of inequality focuses on class inequalities; reference to other inequalities is minimal. Most of the analysis of non-class inequalities does not use the concept of neoliberalism or address the macrolevel. This needs to change, so gender and other inequalities are included.

The approach here builds on Walby (2009) in treating inequalities as systems of social relations, as regimes of inequality. Each of these regimes of inequality is constituted by social relations in four institutional domains: economy, polity, civil society and violence. Each of these institutional domains is a system. This conceptual manoeuvre allows for each institutional domain to be constituted by multiple intersecting regimes of inequality, not just one.

Thinking about the future of gender equality in Europe and the nature and significance of projects opposing it, requires answering the question as to whether Europe is cascading into fascism. This requires: includ- 
ing gender in macro level concepts of neoliberalism, fascism and social democracy; including violence in theories of society; and theorising Europe as a society not only polity.

While fascism is a benchmark, drawn from European history, against which current developments may be compared, it is not an appropriate concept to capture the nature of contemporary Europe. The concept of neoliberalism is helpful; but only if it is deepened beyond traditional political economy to include both the institution of violence and multiple inequalities beyond class. The dynamic interconnections between economy, polity, civil society and violence need inclusion in the theory, if the question is to be answered. In short, a concept and theory of society is needed, not just separate institutions.

To theorise Europe requires a theory of society. It requires a theoretical framework that facilitates the conceptualisation of variations in the forms of society. It requires a theoretical framework that engages with the interconnections between institutions of economy, polity, civil society and violence; not merely focused on one or two of these. It requires a concept and theory of 'Europe' as a society, not only of the political institutions of the EU.

The concept of neoliberalism has been useful in providing a focal point for analyses of changes in capitalism, but is under-developed for analysing current developments. While the theoretical framework in which the concept of neoliberalism is embedded has a grip on the processes of removal of democratically developed regulations on capital, there are only a few texts within this framework that analyse the implications of the rise in deployment of violence by the state and in civil society. Authoritarianism is a potential alternative, but its reach is relatively narrow partly because of its focus on the state. Fascism is a fiercer alternative. We are not yet there, since elections are still being held and violence has not reached genocidal levels. A potential trajectory towards fascism can be seen; but there is also resilience. This resilience can be under-estimated, not least because of the relative invisibility of feminism. The concept of neoliberalism is often deployed as if violence is not important; while those of fascism and authoritarianism, more explicitly recognise its relevance.

One of the features of current times is the increased salience of violence. The analysis of regimes of inequality, including those of gender, too frequently leave violence out of focus. The project of European integration is often analysed as if it were focused on economic growth, but it also significantly concerns violence and security. Theories of 'society' should include violence alongside economy, polity and civil society. Including violence in the theorisation of 'Europe' is necessary to answer the question of whether Europe is cascading into fascism. This requires conceptualising gender at the macro level of regimes as well as the meso level of institutions. This requires a renewed theory of society.

\section{Acknowledgments}

I would like to thank Mieke Verloo and participants in the European political science workshop for helpful comments on an earlier version of the article; and my colleagues in the Violence and Society UNESCO Centre, especially Jude Towers, for discussions on the concept of violence.

\section{Conflict of Interests}

The author declares no conflict of interests.

\section{References}

Abels, G., \& MacRae, H. (Eds.). (2016). Gendering European integration theory. Opladen: Barbara Budrich Publishers.

Abels, G., \& Mushaben, J. M. (Eds.). (2012). Gendering the European Union. London: Palgrave Macmillan.

Ahrens, P. (2018). Actors, institutions, and the making of EU gender equality programs. London: Palgrave Macmillan.

Bertalanffy, L. (1968). General systems theory. New York, NY: George Braziller.

Bieling, H. J., \& Diez, T. (2016). Linking gender perspectives to integration theory: The need for dialogue. In G. Abels \& H. MacRae (Eds.), Gendering European integration theory (pp. 279-292). Opladen: Barbara Budrich Publishers.

Bigo, D. (2006) Globalized (in)security: The field and the ban-opticon. In D. Bigo \& A. Tsoukala (Eds.), Illiberal practices of liberal regimes: The (in)security games. Paris: L'Harmattan.

Boje, T., van Steenbergen, B., \& Walby, S. (Eds). (1999). European societies: Fusion or fission? London: Routledge.

Bourdieu, P. (1994). Rethinking the state. Sociological Theory, 12(1), 1-18.

Brenner, N., Peck, J., \& Theodore, N. (2010). Variegated neoliberalization. Global Networks, 10(2), 182-222.

Bruff, I. (2014). The rise of authoritarian neoliberalism. Rethinking Marxism, 26(1), 113-129.

Buzan, B., Wæver, O., \& de Wilde, J. (1998). Security: A new framework for analysis. Boulder: Lynne Rienner.

Cavaghan, R. (2017). Making gender equality happen. London: Routledge.

Chappell, L., \& Waylen, G. (2013). Gender and the hidden life of institutions. Public Administration, 91(3), 599-615.

Chiricos, T. (1987). Rates of crime and unemployment. Social Problems, 34(2), 187-212.

Collins, R. (2008). Violence: A micro-sociological approach. Princeton: Princeton University Press.

Connell, R. W. (1987). Gender and power. Cambridge: Polity.

Crouch, C. (2011). The strange non-death of neoliberalism. Cambridge: Polity. 
della Porta, D. (1995). Social movements, Political violence and the state. Cambridge: Cambridge University Press.

Durbin, S., Page, M., \& Walby, S. (Eds.). (2017). Gender equality and "austerity": Vulnerabilities, resistance and change. Gender, Work and Organization, 24(1), 1-97.

Eisner, M. (2001). Modernization, self-control and lethal violence. British Journal of Criminology, 41, 618-638.

Elias, N. (1994). The civilising process. Oxford: Blackwell. (Original work published 1939)

Elson, D. (2002). International financial architecture: A view from the kitchen. Femina Politica, 1.

Emmenegger, P., Häusermann, S., Palier, B., \& SeelibKaiser, M. (Eds.). (2012). The age of dualizaton: The changing face of inequality in deindustrializing societies. Oxford: Oxford University Press.

Esping-Andersen, G. (1990). The three worlds of welfare capitalism. Cambridge: Polity.

European Commission. (2017). White paper on the future of Europe. Reflections and scenarios for the EU27 by 2015. Brussels, Belgium: European Commission.

Fajnzylber, P., Lederman, D., \& Loayza, N. (2002). Inequality and violent crime. Journal of Law \& Economics, 45(1), 1-39.

Foucault, M. (1991). Governmentality. In G. Burchell, C. Gordon, \& P. Miller (Eds.), The Foucault effect: Studies in governmentality (pp. 87-105). Chicago: Chicago University Press.

Friedman, M. (2002). Capitalism and freedom. Chicago: University of Chicago Press.

Galtung, J. (1996). Peace by peaceful means. London: Sage and PRIO.

Gane, N. (2014). Sociology and neoliberalism. Sociology, 48(6), 1092-1106.

Garland, D. (2001). The culture of control. Oxford: Oxford University Press.

Gottfredson, M. R., \& Hirschi, T. (1990). A general theory of crime. Stanford: Stanford University Press.

Gottfried, H. (2015). The reproductive bargain: Deciphering the enigma of Japanese capitalism. Leiden: Brill.

Gramsci, A. (1971). Selections from the prison notebooks. London: Lawrence Wishart.

Guerrina, R., Chappell, L., \& Wright, K. (2018). Transforming CSDP? Feminist triangles and gender regimes. Journal of Common Market Studies, 56(5), 1-17.

Haas, E. (1958). The uniting of Europe. Stanford: Stanford University Press.

Habermas, J. (2012). The crisis of the European Union: A response. Cambridge: Polity.

Hallstein, W. (1973). Europe in the making. New York, NY: Norton.

Harvey, D. (2005). A brief history of neoliberalism. Oxford: Oxford University Press.

Hayek, F. (2001). The road to Serfdom. London: Routledge. Hsieh, C., \& Pugh, M. (1993). Poverty, income inequality and violent crime. Criminal Justice Review, 18(2), 182-202.
Huber, E., \& Stephens, J. D. (2000). Partisan governance, women's employment, and the social democratic service state. American Sociological Review, 65, 323-342.

Jacquot, S. (2015). Transformations in EU gender equality: From emergence to dismantling. London: Palgrave Macmillan.

Jenson, J. (1997). Who cares? Gender and welfare regimes. Social Politics, 4(2), 182-187.

Kaldor, M. (2007). Human security. Cambridge: Polity.

Kantola, J., \& Lombardo, E. (Eds.). (2017). Gender and the economic crisis in Europe. Cham: Palgrave Macmillan.

Kelly, L. (1988). Surviving sexual violence. Cambridge: Polity Press.

Krizsan, A., \& Popa, R. (2010). Europeanization in making policies against domestic violence in central and eastern Europe. Social Politics, 17(3), 379-406.

Kronsell, A. (2016). The power of EU masculinities: A feminist contribution to European integration theory. Journal of Common Market Studies, 54(1), 104-120.

Lewis, J. (1992). Gender and the development of welfare regimes. Journal of European Social Policy, 3, 159-173.

Lewis, R., Dobash, R. E., Dobash, R. P., \& Cavanagh, K. (2001). Law's progressive potential. Social and Legal Studies, 10(1), 105-130.

Lombardo, E. (2017). The Spanish gender regime in the EU context: Changes and struggles in times of austerity. Gender, Work and Organization, 24(1), 20-33.

Lombardo, E., \& Forest, M. (Eds). (2011). The Europeanization of gender equality policies: A discursive sociological approach. Basingstoke: Palgrave Macmillan.

Lowndes, V., \& Roberts, M. (2013). Why institutions matter. Basingstoke: Palgrave Macmillan.

Mahon, R. (2010). After neo-liberalism? The OECD, the World Bank and the Child. Global Social Policy, 10(2), 172-192.

Malešević, S. (2010). The sociology of war and violence. Cambridge: Cambridge University Press.

Mann, M. (2004). Fascists. Cambridge: Cambridge University Press.

Mansley, D. (2014). Collective violence, democracy and protest policing. London: Routledge.

Merton, R. (1938). Social structure and anomie. American Sociological Review, 3(5), 672-682.

Milward, A. (1992). The European rescue of the nationstate. New York, NY: Routledge.

Minsky, H. (2008). Stabilizing an unstable economy (2nd ed.). New York, NY: McGraw-Hill.

Moravcsik, A. (1993). Preferences and power in the European Community. Journal of Common Market Studies, 31, 473-526.

National Police Chiefs' Council. (2016, July 8). Hate crime numbers. National Police Chiefs' Council. Retrieved from https://news.npcc.police.uk/releases/ hate-crime-undermines-the-diversity-and-tolerancewe-should-instead-be-celebrating-1 
Ong, A. (2006). Neoliberalism as exception. Durham: Duke University Press.

Peck, J. (2010). Constructions of neoliberal reason. Oxford: Oxford University Press.

Pinker, S. (2011). The better angels of our nature. London: Allen Lane.

Pratt, T., \& Cullen, F. (2005). Assessing macro-level predictors and theories of crime. Crime and Justice, 32, 373-450.

Ray, L. (2011). Violence and society. London: Sage.

Ray, L., \& Smith, D. (2001). Racist offenders and the politics of hate crime. Law and Critique, 12(3), 203-221.

Robinson, W., \& Barrera, M. (2012). Global capitalism and twenty-first century fascism. Race \& Class, 53(3), 4-29.

Schäfer, A., \& Gottschall, K. (2015). From wage regulation to wage gap: How wage-setting institutions and structures shape the gender wage gap across three industries in 24 European countries and Germany. Cambridge Journal of Economics, 39(2), 467-496.

Smith, K. (2003). European Union foreign policy in a changing world. Cambridge: Polity.

Streeck, W. (2014). Buying time. London: Verso.

Tilly, C. (1990). Coercion, capital and European states. Oxford: Blackwell.

Verloo, M. (2006). Multiple inequalities, intersectionality and the European Union. European Journal of Women's Studies, 13(3), 211-228.

Verloo, M. (Ed.). (2018). Varieties of opposition to gender equality. London: Routledge.

Wacquant, L. (2009). Punishing the poor. Durham: Duke University Press.

Wacquant, L. (2010). Crafting the neoliberal state. Sociological Forum, 25(2), 197-220.

Walby, S. (2007). Complexity theory, systems theory and multiple intersecting social inequalities. Philosophy of the Social Sciences, 37(4), 449-470.
Walby, S. (2009). Globalization and inequalities. London: Sage.

Walby, S. (2011). The future of feminism. Cambridge: Polity.

Walby, S. (2013). Violence and society. Current Sociology, 61(2), 95-111.

Walby, S. (2015). Crisis. Cambridge: Polity Press.

Walby, S., Olive, P., Towers, J., Francis, B., Strid, S., Krizsan, A., . . . Armstrong, J. (2015). Stopping rape: Towards a comprehensive policy. Bristol: Policy Press.

Walby, S., Towers, J., Balderston, S., Corradi, C., Francis, B., Heiskanen, M., . . . Strid, S. (2017). The concept and measurement of violence against women and men. Bristol: Policy Press.

Walby, S., Towers, J., \& Francis, F. (2014). Mainstreaming domestic and gender-based violence into sociology and the criminology of violence. The Sociological Review, 62(S2), 187-214.

Walby, S., Towers, J., \& Francis, B. (2016). Is violent crime increasing or decreasing? British Journal of Criminology, 56(6), 1203-1234.

Waylen, G. (2007). Engendering transitions. Oxford: Oxford University Press.

Weldon, L., \& Htun, M. (2012). The civic origins of progressive policy change. American Political Science Review, 106(3), 548-569.

Wöhl, S. (2014). The state and gender relations in international political economy: A state-theoretical approach to varieties of capitalism in crisis. Capital and Class, 38(1), 87-99.

Zielonka, J. (2006). Europe as empire. Oxford: Oxford University Press.

Zippel, K. (2006). The politics of sexual harassment: $A$ comparative study of the United States, the European Union, and Germany. Cambridge: Cambridge University Press.

\section{About the Author}

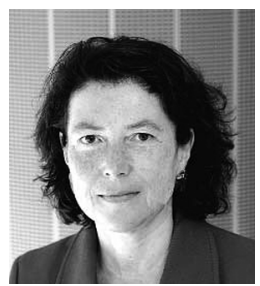

Sylvia Walby (OBE AcSS FRSA) is Distinguished Professor of Sociology, UNESCO Chair in Gender Research, and Director of the Violence and Society UNESCO Centre at Lancaster University, UK. She was the founding President of the European Sociological Association. Books include: Globalization and Inequalities: Complexity and Contested Modernities (Sage, 2009), The Future of Feminism (Polity 2011), and Crisis (Polity, 2015). 